Journal of Universal Mathematics

Vol.3 No.1 PP.46-52 (2020)

ISSN-2618-5660

\title{
INTERPRETATION OF PHYSICAL CONDITIONS OF SCHOOLS WITH FUZZY MULTI CRITERIA DECISION MAKING
}

\author{
FERIDE TUĞRUL, MEHMET ÇITIL, BEYZA KARASOLAK, AND MEHMET DAĞLI
}

\begin{abstract}
The education system has 4 basic elements. These; education system, educator, student (education student) and physical facility. In this study, the physical condition is researched. The aim of this study is to evaluate and interpret the suitability of the physical structures of schools in terms of education and training according to teachers by the multi-criteria decision making method in fuzzy logic. One of the factors affecting success is the physical structure. This study has been conducted with the help of teachers' ideas to determine whether physical structure has an impact on student achievement. This study is an application of a multi-criteria decision-making method, as there are many factors affecting physical structure. In this study 'individual interview' technique has been applied to interpret physical conditions of schools. Scores obtained as a result of individual interviews have been interpreted using multi-criteria decision making method. Teachers' ideas affecting success have been taken into consideration. The results have been compared with the official data.
\end{abstract}

\section{INTRODUCTION}

Fuzzy logic was firstly defined by Zadeh in 1965 [1]. Then, intuitionistic fuzzy sets (shortly IFS) were defined by K.Atanassov in 1986 [2]. IFS form a generalization of the notion of fuzzy sets. Decision making is the action of selecting between two or more options. Multi criteria decision making(MCDM) is a well known notion that aims to choose the best solution among various alternatives in decision making. The working style of all MCDM methods is like this: Selection of Criteria, Selection of Alternatives, Selection of Aggregation Methods and ultimately Selection of Alternatives based on weights or outranking [3]. Some of the MCDM methods are as follows: Analytical Hierarchy Process (AHP), Fuzzy Multi Criteria Decision Making Process, ELECTRE Method, Preference Ranking Organization Method for Enrichment of Evaluations (PROMETHEE), The TOPSIS Method. Bellman and Zadeh the firstly introduced decision making in fuzzy logic. Multi criteria fuzzy decision making has been one of the quickly growing area in recent years on account of its practicality. In MCDM problems, usually the best alternative is chosen from alternatives according to criteria.

2000 Mathematics Subject Classification. 03E72,90B50.

Key words and phrases. Fuzzy sets, Multi criteria decision making.

The first author was supported by 2211 TUBITAK Domestic PhD Scholarship Program. 
The aim of this study is to evaluate and interpret the suitability of the physical structures of schools in terms of education and training according to teachers by the multi-criteria decision making method in fuzzy logic. One of the factors affecting success is the physical structure. This study has been conducted with the help of teachers' ideas to determine whether physical structure has an impact on student achievement. This issue has recently attracted the attention of many researchers $[6],[7],[8],[9]$. This study is an application of a multi-criteria decisionmaking method, as there are many factors affecting physical structure. In this study 'individual interview' technique has been applied to interpret physical conditions of schools. Individual interview questions have been prepared by us by reviewing the literature. Scores obtained as a result of individual interviews have been interpreted using multi-criteria decision making method. Teachers' ideas affecting success have been taken into consideration. The results have been compared with the official data. This study was carried out in schools in Kahramanmaraş city in Turkey. 19 questions were asked to each teacher in 9 schools from different regions. The questions within the same criterion were combined into a total of 11 criteria. Each question is scored between 1-10. Teachers were been wanted to be objective in answering questions, but teachers were not objective. This is because some teachers want to protect their school so they don't want to give a low score. Schools have a great importance in student success. School buildings are developing and changing day by day. The following criteria can be considered to determine the suitability of physical conditions of schools for education:

- Location

- Heat

- Sunlight

- Noise

- Color

- Capacity

- Library

- Kafe

- Garden, Green Field

- Cleaning

- Technology

According to official data obtained from the Ministry of National Education, below are the features that should be in the criteria [10]:

- Location: The location of the buildings close to the settlement. Low traffic density. Be easily accessible by public transport.

- Heat: The ideal temperature is considered to be 17-23 degrees.

- Sunlight: South direction should be preferred for more sunlight in the settlement of buildings.

- Noise: To minimize noise, sound insulation should be made to the building. If necessary, sound devices must be installed. Double glazing should be used in the windows.

- Color: Live and warm colors should be used in doors and windows. Pastel colors should be preferred indoors.

- Capacity: Classes must have a maximum capacity of 30 students. 
- Library: In a quiet area, with internet connection, suitable for group and individual work sitting system, sound insulation, large book store.

- Kafe: Ground floor, dining and resting place, healthy food and beverage sale.

- Garden, Green Field: There should be volleyball, football, basketball courts. There should be trees in the garden, no parking.

- Cleaning: For the health of students and teachers, care must be taken to clean school, toilet, classroom and garden.

- Technology: Computer labs for students, smart boards in classrooms, tablets.

\section{PRELIMINARIES}

Definition 2.1. [1] Let $X$ be a nonempty set. A fuzzy set $A$ drawn from $X$ is defined as $A=\left\{\left\langle x, \mu_{A}(x)\right\rangle \mid x \in X\right\}$, where $\mu_{A}(x): X \rightarrow[0,1]$ is the membership function of the fuzzy set $A$.

TOPSIS method has been used in this study. TOPSIS was proposed by Hwang and Yoon (1981) to determine the best alternative based on the concepts of the compromise solution [5]. The compromise solution can be regarded as choosing the solution with the shortest Euclidean distance from the ideal solution and the farthest Euclidean distance from the negative ideal solution. The procedures of TOPSIS can be described as follows [4],[5]:

Given a set of alternatives $A=\left\{A_{k} \mid k=1,2, \cdots, n\right\}$ and a set of criteria $C=$ $\left\{C_{j} \mid j=1,2, \cdots, m\right\}$ where $X=\left\{x_{k j} \mid k=1,, \cdots, n ; j=1, \cdots, m\right\}$ denotes the set of performance ratings and $w=\left\{w_{j} \mid j=1, \cdots, m\right\}$ is the set of weights. The first step of TOPSIS is to calculate normalized ratings by [12]:

$$
r_{k j}(x)=\frac{x_{k j}}{\sqrt{\sum_{k=1}^{n} x_{k j}^{2}}}, k=1, \cdots, n ; j=1, \cdots, m .
$$

- For benefit criteria (larger is better); $r_{k j}(x)=\left(x_{k j}-x_{j}^{-}\right) /\left(x_{j}^{*}-x_{j}^{-}\right)$, where $x_{j}^{*}=\max _{k} x_{k j}$ and $x_{j}^{-}=\min _{k} x_{k j}$ or setting $x_{j}^{*}$ is the desired level and $x_{j}^{-}$ is the worst level.

- For non benefit criteria (smaller is better); $r_{k j}(x)=\left(x_{j}^{-}-x_{k j}\right) /\left(x_{j}^{-}-x_{j}^{*}\right)$, and then to calculate weighted normalized ratings by

$$
v_{k j}(x)=w_{j} r_{k j}(x), k=1, \cdots, n ; j=1, \cdots, m .
$$

Next the positive ideal point (PIS) and the negative ideal point (NIS) are derived as [12];

$$
\begin{aligned}
P I S=A^{+} & =\left\{v_{1}^{+}(x), v_{2}^{+}(x), \cdots, v_{j}^{+}(x), \cdots, v_{m}^{+}(x)\right\} \\
& =\left\{\left(\max v_{k j}(x) \mid j \in J_{1}\right),\left(\min v_{k j}(x) \mid j \in J_{2}\right) \mid k=1, \cdots, n\right\} \\
N I S=A^{-} & =\left\{v_{1}^{-}(x), v_{2}^{-}(x), \cdots, v_{j}^{-}(x), \cdots, v_{m}^{-}(x)\right\} \\
& =\left\{\left(\min v_{k j}(x) \mid j \in J_{1}\right),\left(\max v_{k j}(x) \mid j \in J_{2}\right) \mid k=1, \cdots, n\right\}
\end{aligned}
$$

where $J_{1}$ and $J_{2}$ are the benefit and the non benefit attributes, respectively. The next step is to calculate the separation from the PIS and the NIS between 
alternatives. The separation values can be measured using the Euclidean distance, which is given as:

$$
\begin{aligned}
& D_{k}^{+}=\sqrt{\sum_{j=1}^{m}\left[v_{k j}(x)-v_{j}^{+}(x)\right]^{2}}, k=1, \cdots, n . \\
& D_{k}^{-}=\sqrt{\sum_{j=1}^{m}\left[v_{k j}(x)-v_{j}^{-}(x)\right]^{2}}, k=1, \cdots, n .
\end{aligned}
$$

The similarities to the PIS can be derived as:

$$
C_{k}^{*}=\frac{D_{k}^{-}}{\left(D_{k}^{+}+D_{k}^{-}\right)}, k=1, \cdots, n .
$$

where $C_{k}^{*} \in[0,1], \forall k=1, \cdots, n$.

Finally, the preferred orders can be obtained according to the similarities to the $P I S\left(C_{k}^{*}\right)$ in descending order to choose the best alternatives.

\section{Interpretation of Physical Conditions of Schools}

In this study 'individual interview' technique has been applied to interpret physical conditions of schools. This study was carried out in schools in Kahramanmaraş city in Turkey. 19 questions were asked to each teacher in 9 schools from different regions. The questions within the same criterion were combined into a total of 11 criteria. Each question is scored between 1-10. The answers given to each question were calculated as fuzzy value. In this study, a total of 9 school represent alternatives, 11 questions asked to teachers in the individual interview represent the criteria. $O=\left\{O_{1}, O_{2}, O_{3}, O_{4}, O_{5}, O_{6}, O_{7}, O_{8}, O_{9}\right\}$ set of alternatives. $C=$ $\left\{C_{1}, C_{2}, C_{3}, C_{4}, C_{5}, C_{6}, C_{7}, C_{8}, C_{9}, C_{10}, C_{11}\right\}$ set of criteria. Set of criteria is respectively $\{$ Location, Heat, Sunlight, Noise, Color, Capacity, Library, Kafe, GardenGreenField, Cleaning, Technology $\}$ In the following table, the average of fuzzy values of the answers given by the teachers in the individual interview questions was calculated and a score was calculated for each school.

Step 1: Determine the alternatives and criteria in Table 1.

\begin{tabular}{|l|l|l|l|l|l|l|l|l|l|l|l|}
\hline & $C_{1}$ & $C_{2}$ & $C_{3}$ & $C_{4}$ & $C_{5}$ & $C_{6}$ & $C_{7}$ & $C_{8}$ & $C_{9}$ & $C_{10}$ & $C_{11}$ \\
\hline$O_{1}$ & 0.779 & 0.721 & 0.729 & 0.314 & 0.593 & 0.369 & 0.579 & 0.4 & 0.39 & 0.45 & 0.582 \\
\hline$O_{2}$ & 0.832 & 0.864 & 0.782 & 0.655 & 0.727 & 0.612 & 0.658 & 0.745 & 0.7 & 0.773 & 0.692 \\
\hline$O_{3}$ & 0.804 & 0.833 & 0.825 & 0.358 & 0.825 & 0.714 & 0.475 & 0.517 & 0.654 & 0.858 & 0.823 \\
\hline$O_{4}$ & 0.88 & 0.875 & 0.692 & 0.375 & 0.717 & 0.719 & 0.645 & 0.558 & 0.805 & 0.675 & 0.672 \\
\hline$O_{5}$ & 0.796 & 0.775 & 0.733 & 0.383 & 0.7 & 0.706 & 0.853 & 0.75 & 0.734 & 0.667 & 0.698 \\
\hline$O_{6}$ & 0.967 & 0.958 & 1 & 0.883 & 0.925 & 0.986 & 0.948 & 0.875 & 0.967 & 1 & 0.966 \\
\hline$O_{7}$ & 0.855 & 0.758 & 0.825 & 0.683 & 0.842 & 0.839 & 0.708 & 0.808 & 0.75 & 0.85 & 0.797 \\
\hline$O_{8}$ & 0.912 & 0.733 & 0.867 & 0.65 & 0.783 & 0.881 & 0.82 & 0.833 & 0.779 & 0.833 & 0.475 \\
\hline$O_{9}$ & 0.417 & 0.65 & 0.9 & 0.2 & 0.65 & 0.578 & 0.638 & 0.642 & 0.554 & 0.625 & 0.551 \\
\hline
\end{tabular}

Table 1 
Step 2: Calculate normalised matrix using by Equation 2.1 in Table 2.

\begin{tabular}{|l|l|l|l|l|l|l|l|l|l|l|l|}
\hline & $C_{1}$ & $C_{2}$ & $C_{3}$ & $C_{4}$ & $C_{5}$ & $C_{6}$ & $C_{7}$ & $C_{8}$ & $C_{9}$ & $C_{10}$ & $C_{11}$ \\
\hline$O_{1}$ & 0.317 & 0.3 & 0.296 & 0.192 & 0.261 & 0.168 & 0.269 & 0.191 & 0.18 & 0.196 & 0.273 \\
\hline$O_{2}$ & 0.339 & 0.36 & 0.317 & 0.402 & 0.319 & 0.278 & 0.306 & 0.356 & 0.324 & 0.337 & 0.325 \\
\hline$O_{3}$ & 0.327 & 0.347 & 0.335 & 0.219 & 0.363 & 0.325 & 0.221 & 0.247 & 0.302 & 0.374 & 0.386 \\
\hline$O_{4}$ & 0.358 & 0.364 & 0.281 & 0.23 & 0.315 & 0.327 & 0.3 & 0.266 & 0.372 & 0.294 & 0.315 \\
\hline$O_{5}$ & 0.324 & 0.322 & 0.297 & 0.235 & 0.308 & 0.321 & 0.397 & 0.358 & 0.339 & 0.291 & 0.328 \\
\hline$O_{6}$ & 0.394 & 0.399 & 0.406 & 0.542 & 0.407 & 0.449 & 0.441 & 0.418 & 0.447 & 0.436 & 0.453 \\
\hline$O_{7}$ & 0.348 & 0.315 & 0.335 & 0.419 & 0.37 & 0.382 & 0.329 & 0.386 & 0.347 & 0.371 & 0.374 \\
\hline$O_{8}$ & 0.371 & 0.305 & 0.352 & 0.399 & 0.344 & 0.401 & 0.381 & 0.398 & 0.36 & 0.363 & 0.223 \\
\hline$O_{9}$ & 0.169 & 0.27 & 0.365 & 0.122 & 0.286 & 0.263 & 0.297 & 0.307 & 0.256 & 0.273 & 0.258 \\
\hline
\end{tabular}

Table 2

Step 3: Determine weight of criteria as shown as in Table 3 and calculate weighted normalised matrix using by Equation 2.2 in Table 4;

The weights of the criteria were determined according to their importance. The weights of the criteria may vary for different situations if desired. Where $w_{j}, j=$ $1, \cdots, 11$ represents weights of criteria.

\begin{tabular}{|l|l|l|l|l|l|l|l|l|l|l|l|}
\hline & $C_{1}$ & $C_{2}$ & $C_{3}$ & $C_{4}$ & $C_{5}$ & $C_{6}$ & $C_{7}$ & $C_{8}$ & $C_{9}$ & $C_{10}$ & $C_{11}$ \\
\hline$w_{j}$ & 0.12 & 0.12 & 0.09 & 0.12 & 0.05 & 0.12 & 0.08 & 0.05 & 0.05 & 0.08 & 0.12 \\
\hline
\end{tabular}

Table 3

\begin{tabular}{|l|l|l|l|l|l|l|l|l|l|l|l|}
\hline & $C_{1}$ & $C_{2}$ & $C_{3}$ & $C_{4}$ & $C_{5}$ & $C_{6}$ & $C_{7}$ & $C_{8}$ & $C_{9}$ & $C_{10}$ & $C_{11}$ \\
\hline$O_{1}$ & 0.038 & 0.036 & 0.026 & 0.023 & 0.013 & 0.02 & 0.021 & 0.009 & 0.009 & 0.015 & 0.032 \\
\hline$O_{2}$ & 0.04 & 0.043 & 0.028 & 0.048 & 0.015 & 0.033 & 0.024 & 0.017 & 0.016 & 0.026 & 0.039 \\
\hline$O_{3}$ & 0.039 & 0.041 & 0.03 & 0.026 & 0.018 & 0.039 & 0.017 & 0.012 & 0.015 & 0.029 & 0.046 \\
\hline$O_{4}$ & 0.042 & 0.043 & 0.025 & 0.027 & 0.015 & 0.039 & 0.024 & 0.013 & 0.018 & 0.023 & 0.0 .37 \\
\hline$O_{5}$ & 0.038 & 0.038 & 0.026 & 0.028 & 0.015 & 0.038 & 0.031 & 0.017 & 0.016 & 0.023 & 0.0 .39 \\
\hline$O_{6}$ & 0.047 & 0.047 & 0.036 & 0.065 & 0.02 & 0.053 & 0.035 & 0.02 & 0.022 & 0.034 & 0.054 \\
\hline$O_{7}$ & 0.041 & 0.037 & 0.03 & 0.05 & 0.018 & 0.045 & 0.026 & 0.019 & 0.017 & 0.029 & 0.044 \\
\hline$O_{8}$ & 0.044 & 0.036 & 0.031 & 0.047 & 0.017 & 0.048 & 0.03 & 0.019 & 0.018 & 0.029 & 0.026 \\
\hline$O_{9}$ & 0.02 & 0.032 & 0.032 & 0.014 & 0.014 & 0.031 & 0.023 & 0.015 & 0.012 & 0.021 & 0.03 \\
\hline
\end{tabular}

Table 4

Step 4: Calculate the positive ideal point $(P I S)$ and negative ideal point $(N I S)$ using by Equation 2.3 and 2.4

\begin{tabular}{|c|l|l|l|l|l|l|l|l|l|l|l|}
\hline PIS/NIS & $C_{1}$ & $C_{2}$ & $C_{3}$ & $C_{4}$ & $C_{5}$ & $C_{6}$ & $C_{7}$ & $C_{8}$ & $C_{9}$ & $C_{10}$ & $C_{11}$ \\
\hline$A^{+}$ & 0.047 & 0.047 & 0.036 & 0.065 & 0.02 & 0.053 & 0.035 & 0.02 & 0.022 & 0.034 & 0.054 \\
\hline$A^{-}$ & 0.02 & 0.032 & 0.025 & 0.014 & 0.013 & 0.02 & 0.017 & 0.009 & 0.009 & 0.015 & 0.026 \\
\hline
\end{tabular}

Table 5

Step 5: Calculate separation values using by Euclidean distance (Equation 2.5,2.6) 


\begin{tabular}{|l|l|l|}
\hline & $D_{k}^{+}$ & $D_{k}^{-}$ \\
\hline$O_{1}$ & 0.0673 & 0.0217 \\
\hline$O_{2}$ & 0.036 & 0.048 \\
\hline$O_{3}$ & 0.0488 & 0.0404 \\
\hline$O_{4}$ & 0.0492 & 0.0383 \\
\hline$O_{5}$ & 0.0478 & 0.0377 \\
\hline$O_{6}$ & 0 & 0.081 \\
\hline$O_{7}$ & 0.0264 & 0.0565 \\
\hline$O_{8}$ & 0.0369 & 0.0553 \\
\hline$O_{9}$ & 0.0714 & 0.0174 \\
\hline
\end{tabular}

Table 6

Step 6: Calculate performance score using by Equation 2.7 and ranking of alternatives;

\begin{tabular}{|l|l|l|}
\hline & $C_{k}$ & Ranking \\
\hline$O_{1}$ & 0.2438 & 8 \\
\hline$O_{2}$ & 0.5714 & 4 \\
\hline$O_{3}$ & 0.4529 & 5 \\
\hline$O_{4}$ & 0.4377 & 7 \\
\hline$O_{5}$ & 0.4409 & 6 \\
\hline$O_{6}$ & 1 & 1 \\
\hline$O_{7}$ & 0.6815 & 2 \\
\hline$O_{8}$ & 0.5997 & 3 \\
\hline$O_{9}$ & 0.1959 & 9 \\
\hline
\end{tabular}

Table 7

\section{Conclusion}

If we make a ranking according to the physical conditions of schools; $O_{6}, O_{7}, O_{8}$, $\mathrm{O}_{2}, \mathrm{O}_{3}, \mathrm{O}_{5}, \mathrm{O}_{4}, \mathrm{O}_{1}, \mathrm{O}_{9}$. So physical conditions are the most appropriate school: $\mathrm{O}_{6}$. This ranking was made according to the data obtained from the individual interview. According to the teachers $C_{1}, C_{2}, C_{4}, C_{6}, C_{11}$ criteria are more important than the other criteria. Therefore, the weight values of these criteria were calculated high during the study. Only physical conditions of schools were interpreted in this study. The success rankings of schools according to official data are as follows: $\mathrm{O}_{6}, \mathrm{O}_{8}, \mathrm{O}_{7}, \mathrm{O}_{4}, \mathrm{O}_{5}, \mathrm{O}_{9}, \mathrm{O}_{1}, \mathrm{O}_{2}, \mathrm{O}_{3}$. If desired, a similar or different method can be used for the success of schools. Or the relationship between success and physical conditions can be examined. (As in the paper [11])

The aim of this study is to evaluate and interpret the suitability of the physical structures of schools in terms of education and training according to teachers by the multi-criteria decision making method in fuzzy logic.Teachers were been wanted to be objective in answering questions, but teachers were not objective. This is because some teachers want to protect their school so they don't want to give a low score.bAccording to the teachers, success will increase as physical conditions become appropriate. Especially; Location, Heat, Noise, Capacity, Library, Technology criteria are more important than other criteria according to teachers. Of course, there are many factors that affect success. Physical conditions of schools are just one of 
these factors.According to this study, physical conditions of school buildings can be changed or redesigned. In addition, the new school buildings should be constructed considering the physical conditions.

Our aim is to produce more systematic more rational solutions. Minister of National education of Turkey is planning to present a new system in Turkey in line with these ideas according to the new vision of education. We hope that this study and similar studies will contribute to the new system. With this method, applications can be made in many areas. This study can be adapted to any area. We hope that this study will lead other studies.

\section{REFERENCES}

[1] Zadeh. L.A. Fuzzy Sets, Information and Control, Vol.8, pp.338-353, (1965).

[2] Atanassov, K. Intuitionistic fuzzy sets, Fuzzy Sets and Systems, Vol.20, No.1, pp.87-96, (1986).

[3] Majumder. M, Multi Criteria Decision Making, Chapter 2, Springer, pp.35-47, (2015).

[4] Nadaban. S, Dzitac. S, Dzitac. I, Fuzzy TOPSIS: A General View, Information Technology and Quantitative Management, 823-831, (2016).

[5] Hwang CL, Yoon KP. Multiple Attribute Decision Making: Methods and Applications, A State-of-the-Art Survey. Berlin: Springer-Verlang; (1981).

[6] Akbaba. A, Turhan. M, Ilköğretim Okul Binalarının Fiziksel Sorunlarına İlişkin Öğretmen Görüşlerinin Incelenmesi (Van Il Örneǵi), KTÜ Sosyal Bilimler Dergisi, 6(12), (2016).

[7] Şensoy. S, Sağsöz. A, Öğrenci Başarısının Sınıfların Fiziksel Koşulları İle İlişkisi, Ahi Evran Üniversitesi Kırşehir Eğitim Fakültesi Dergisi, Vol.16, No.3, pp.87-104, (2015).

[8] Yılmaz. A, İlköğretim Okullarının Fiziksel Yapılarının Eğitim Ve Öğretim Açısından Değerlendirilmesi,Balikesir University The Journal of Social Sciences Institute, Vol.15, No.28, pp.77-107, (2012).

[9] Aydoğan. İ, Okul Binalarının Özellikleri ve Öğrenciler Üzerine Etkileri, Milli Eğitim Dergisi, Vol.193, pp.29-43, (2012).

[10] Milli Eğitim Bakanlı̆̆ı, Eğitim Yapıları Asgari Tasarım Standartları Kılavuzu, (2015).

[11] Tuğrul. F, Çitil. M, Yılmaz. B, School Success Ranking in Multi Criteria Decision Making, Turk. J. Math. Comput. Sci., Vol.10, pp.1-6, (2018).

[12] Tzeng. G.H, Huang. J.J, Multiple Attribute Decision Making, CRC press, Unites States of America, (2011).

Department of Mathematics, Kahramanmaraş SÜtcü İmam University, Kahramanmaraş, TURKEY

Email address: feridetugrul@gmail.com,citil@ksu.edu.tr 